якісного моніторингу та семантичного аналізу текстових документів [1].

Отже, виявлення особливостей інформаційного простору, у межах якого буде здійснювати свою діяльність майбутній перекладач, дозволить акцентувати увагу на формуванні в нього у процесі навчання у ВНЗ відповідних інформаційних компетенцій, що забезпечать йому задоволення інформаційних потреб, які виникають у його професійній діяльності в умовах інформаційного суспільства. Перспективи подальших досліджень пов'язані із вивченням засобів формування інформаційної компетентності майбутніх перекладачів.

\title{
Література
}

1. Національний інформаційний суверенітет в контексті розвитку інформаційних технологій / [О. С. Онищенко, В. М. Горовий, В. І. Попик та ін.]; НАН України, Нац. б-ка України ім. В. І. Вернадського. - К. : НБУВ, 2011. - 160 с. 2. Плунгян В. А. Почему современная лингвистика должна быть лингвистикой корпусов?: (публичная лекция, прочитанная 01.10.2009) [Электронный ресурс] / В. А. Плунгян. - Режим доступу : $\quad$ http://www.polit.ru/lectures/2009/10/23/corpus.html. 3. Пресcрелиз [Электронный ресурс]/ Режим доступу : http://ukraine.emc.com/about/news/press/2012/20121211-01.htm 4. Стратегія формування та розвитку національного інформаційного простору України - Державна інформаційна політика [Електронний ресурс] / I. В. Арістова. - Режим доступу: http://www.pravo.vuzlib.org/book_z1189_page_15.html

УДК $371.13: 51$

Ніна Тарасенкова, Оксана Коваленко

\section{МЕТОДИЧНІ ОСОБЛИВОСТІ НАВЧАННЯ МАТЕМАТИКИ МАЙБУТНІХ УЧИТЕЛІВ ПОЧАТКОВОЇ ШКОЛИ}

Тарасенкова Н. А., Коваленко О. А. Методичні особливості навчання математики майбутніх учителів початкової школи.

У статті розглядається один із дидактичних підходів до систематизації знань студентів теоретичного матеріалу з теми «Вирази» та вдосконалення їх умінь розв’язувати практичні і творчі завдання, що забезпечує обізнаність майбутнього вчителя початкової школи щодо змісту навчального матеріалу з математики та сприяє формуванню його професійної компетентності.

Ключові слова: майбутні вчителі початкової школи, навчання математики, вирази, вирази зі змінними, компетентність, професійна підготовка.

Тарасенкова Н. А., Коваленко О. А. Методические особенности обучения математике будущих учителей начальной школы.

В статье рассматривается один из дидактических подходов к систематизации знаний студентов теоретического материала по теме «Выражения» и усовершенствование их умений решать практические и творческие задания, что обеспечивает осведомленность будущего учителя начальной школы в содержании учебного материала по математике и способствует формированию его профессиональной компетентности.

Ключевые слова: будущие учителя начальной школы, обучение математике, выражения, выражения с переменными, компетентность, профессиональная подготовка. 
Tarasenkova N. A., Kovalenko O. A. Methodical features of the teaching of mathematics for the future primary school teachers.

The article deals with one of the didactic approaches of systematizing the knowledge of theoretical material on «Expressions» of students and improving their skills to solve practical and creative tasks that makes awareness of the future primary school teacher in the content of the educational material in mathematics and contributes to the formation of his professional competence.

Key words: future primary school teachers, teaching mathematics, expressions, expressions with variables, competence, training.

На сучасному етапі розвитку суспільства, переорієнтації соціальних відносин, розширення культурних меж відбуваються зміни й у галузі освіти. Одним із напрямів удосконалення шкільної математичної підготовки учнів $\epsilon$ пошук шляхів і засобів створення найсприятливіших умов для продуктивного навчання і розвитку кожного школяра, починаючи з молодших класів. У зв'язку з цим нових підходів потребує оцінка місця і ролі математичної підготовки учнів та майбутніх учителів початкової школи [8].

Навчання математики студентів - майбутніх учителів молодшої школи часто породжує у них появу внутрішніх суперечностей: між новими пізнавальними цілями та наявними способами дій; між новими ситуаціями та попереднім досвідом; між узагальненнями, які склалися, i новими фактами тощо. Але необхідність їх усвідомлення студентами, розгортання активної діяльності, спрямованої на їх усунення, $\epsilon$ головною задачею професійної підготовки майбутнього вчителя початкових класів. I не останню роль у цьому відіграють дидактично виважені підходи до формування не лише предметної, а й психолого-педагогічної компетентності студентів. Майбутньому вчителю початкової школи щонайперше треба бути добре обізнаним із віковими особливостями школярів.

Дітям молодшого шкільного віку притаманна суттєва різниця в математичних знаннях, особливо на початковій стадії вивчення (1 клас) - одні довго не можуть запам'ятати назву цифр, а інші вільно рахують в межах 20 і навіть 100, безпомилково виконують дії додавання та віднімання. Тому ознакою високого професіоналізму вчителя $\epsilon$ вміння виховати у дітей позитивне ставлення до процесу навчання взагалі, інтерес до навчальних предметів, зокрема математики. За умов сформованості у студентів - майбутніх учителів початкової школи професійного ставлення до вивчення курсу математики та курсу методики навчання математики як специфічних, професійно зорієнтованих дисциплін в університеті значно полегшиться в майбутній професійній діяльності розв'язання проблеми створення психологічно комфортного клімату для активного, усвідомленого й зацікавленого учіння молодших школярів, ïx вільного просування в навчанні та особистісного зростання.

Метою статті є окреслення особливостей вивчення теми «Вирази» в курсі «Математика» студентами - майбутніми вчителями початкових класів.

Тема «Вирази» досить актуальна для вивчення студентами - майбутніми вчителями початкової школи, оскільки ii засвоєння забезпечує готовність й уміння ефективного застосування цих знань на практиці, подолання труднощів, які можуть виникати в ході професійної діяльності.

Майбутній учитель початкових класів має знати, що мова, якої навчаються учні, надає їм можливості виражати себе, збагачувати свій світ, залучаючи до нього 
загальнолюдські надбання. Засвоєння інших знако-символічних систем, зокрема наукових мов, сприяє розвитку інформаційної культури учнів [8].

Навчання математики на всіх його етапах означає і навчання математичної мови та іiї культури [7].

На нашу думку, на одному 3 лекційних занять доцільно розглянути тему «Вирази». Вивчення цієї теми можна розпочати нагадуванням того факту, що математична мова виникла у зв'язку з необхідністю точного, стислого і однозначного формулювання математичних законів, означень, доведень. Вона, як й інші мови, має свою знако-символічну систему, що складається з: десяти цифр, за допомогою яких здійснюється запис чисел у десятковій системі числення $(0,1,2,3,4,5,6,7,8,9)$; малих і великих літер латинського алфавіту, за допомогою яких позначають змінні, множини та їх елементи $(a, b, c, d, \ldots, z, A, B, \ldots, Z)$; літер грецького алфавіту, за допомогою яких позначають кути, площини $(\alpha, \beta, \gamma, \ldots \varphi, \ldots)$; знаків дій $(+,-$, $\cdot \div, \cup, \cap, \ldots)$; з знаків відношень $(=,>,<, \perp, \|, \ldots) ; \quad$ різних дужок $((),\{\},[], \ldots) ;$ знаків факторіала та інтеграла тощо.

Математичні слова, вирази, речення будують за допомогою поєднання різноманітних математичних символів.

Нагадаємо, що ознайомлення учнів 3 найпростішими числовими й буквеними виразами та діями 3 ними розпочинається на уроках математики в початковій школі. Завдання в підручниках 3 математики для 1-4 класів зазвичай мають такі формулювання [1-5]: обчисли значення виразу; обчисли та порівняй значення виразів; склади вираз до задачі; склади задачу за поданим виразом; порівняй буквені вирази із заданими значеннями невідомих; на місце порожніх клітинок постав потрібні числа; постав пропущений знак, щоб утворилася правильна рівність (нерівність); розв’яжи рівняння тощо.

Пізніше, у 5-6 класах, продовжується вивчення числових і буквених виразів та їх перетворень за законами арифметичних дій.

Так, на перший погляд, матеріал, що вивчається в 1-6 класах, - елементарний. Проте незаперечним є той факт, що він створює міцне підгрунтя для вивчення різних розділів математики в 7-11 класах (як алгебри, так і геометрії): вирази зі змінними; вирази, що містять знак модуля, кореня деякого степеня, логарифма, тригонометричних функцій тощо; рівняння; нерівності; одночлени; многочлени; системи рівнянь та нерівностей; текстові задачі; задачі на відшукання невідомих елементів геометричних фігур тощо.

Студентам варто нагадати, що запис одночленів і многочленів у стандартному вигляді, зведення подібних доданків, розкриття дужок і взяття елементів в дужки, розкладання многочленів на множники (винесення спільного множника за дужки, групування), виконання арифметичних дій за їх законами - це види перетворень, які можна виконувати над виразами.

Також доцільно звернути увагу студентів на те, що вирази можуть містити одну або кілька змінних (вирази з однією змінною; вирази $з$ двома, з трьома, з $n$ змінними тощо). Значення виразу, що містить змінну, залежить від значення змінної. Зазвичай, у вирази із змінними підставляють такі значення, щоб можна було отримати числовий вираз, який має зміст. Число, яке підставляють у вираз замість змінної, називається значенням змінної, а множину всіх значень змінної, за яких даний вираз має зміст, називають областю визначення цього виразу. Формулюючи завдання на знаходження значення виразу, що містить змінну, мають на увазі, що змінна може набувати таких 
значень, які належать до області визначення цього виразу. Область визначення виразів може бути заданою будь-якою 3 числових множин (рис. 1) чи їх підмножинами. Проте областю визначення деяких виразів зі змінними може бути порожня множина.

$\boldsymbol{N}$ - множина натуральних чисел;

$\boldsymbol{Z}$ - множина цілих чисел

$\boldsymbol{Q}$ - множина раціональних чисел;

$\boldsymbol{I}$ - множина ірраціональних чисел;

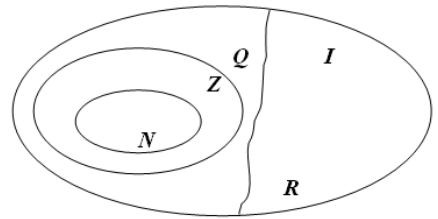

$\boldsymbol{R}$ - множина дійсних чисел.

Рис. 1. Область визначення виразів

За допомогою знаків $=,>,<, \geq, \leq$ можна порівнювати вирази (як числові, так i вирази зі змінними). У результаті такого поєднання (виразів і знаків порівнянь) утворюються математичні речення (висловлення), про які можна сказати, істинні вони чи хибні. Наприклад: 1) істинні висловлення: якщо $a=b$, то $a+c=b+c$; якщо $a=b$, то $a \cdot c=b \cdot c ; 2$ ) хибні висловлення: $8+3=9+4 ; 18: 2>3 \cdot 15$.

На практичному занятті перед викладачем постають такі завдання: 1) навчити студентів орієнтуватися в різновидах виразів та їх назвах, пам'ятати, що назва виразу визначається за заданим виглядом, а не за тим, якого він набуває внаслідок виконаного перетворення; 2) навчити майбутніх учителів початкової школи цілеспрямовано використовувати теоретичні відомості 3 теми під час виконання різних завдань (спрощення виразів, розв'язання рівнянь та нерівностей, доведення тотожностей тощо).

Доречно запропонувати студентам для виконання (під час аудиторної роботи чи самостійної підготовки) такі завдання практичного і пошуково-дослідницького характеру.

1. Встановіть, які записи можна вважати словами математичної мови [6]:

а) $2+3 \cdot 4$; б) $7+12-$; в) $(17+3) \cdot 2 a-18: 2$; г) $\sqrt{16}-; a \cdot b$.

2. Серед наведених записів укажіть математичні речення:

а) $2<3$; б) $x \| y$; в) $5 y \cdot y-3 x+=$; г) $x^{2}-3 x+4=0$.

3. Використовуючи символи математичної мови запишіть два математичні слова, два вирази, два речення [6].

4. Серед наведених записів укажіть: а) числові вирази; б) вирази зі змінними; в) цілі вирази; г) дробові вирази; д) одночлени: е) многочлени: $7 \cdot \sqrt{16-3} ; 5 x ; \sqrt{2} ; 42$ : $(-14 \cdot 2) ; 6-\frac{m+2}{n} ; x+2 y<7 ; \frac{2,3+a c}{5} ; 32: y+3 ; \frac{1}{2}+(2-3)$.

5. Установіть, за яких значень змінних вираз не має змісту:

а) $\frac{64}{3+y}$; б) $\sqrt{a+3}$; в) $\frac{8}{\sqrt{x-4}}$.

6. Знайдіть помилку в схемі (рис. 2): 


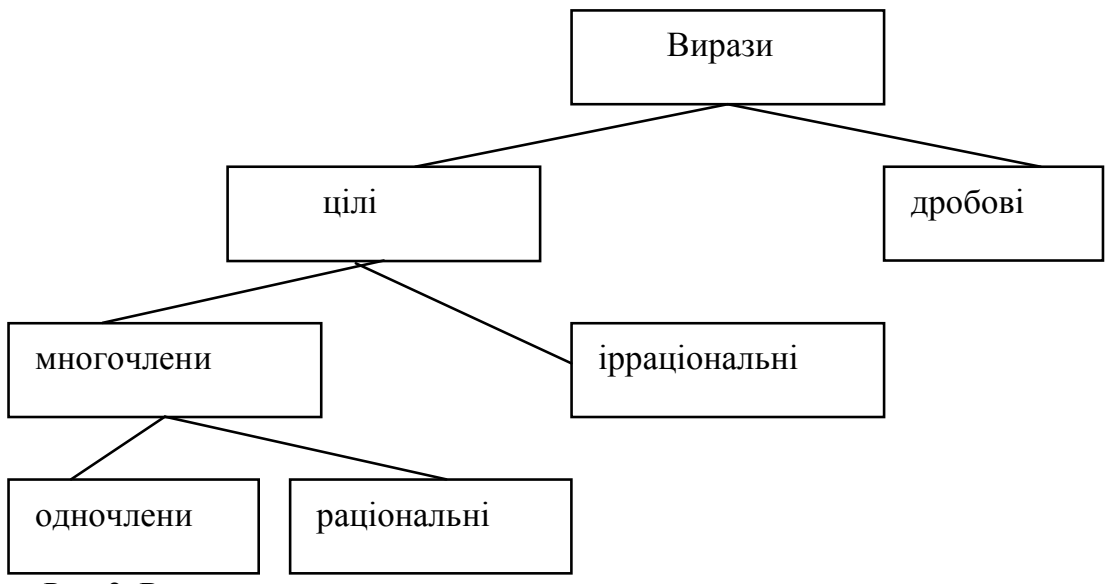

Рис. 2. Вирази

7. Обчисліть значення числового виразу:

а) $(72: 12-(18-15)):(24: 3-2 \cdot 4)$;

б) $(-2,09: 1,1+4,5) \cdot\left(-\frac{5}{8}\right)-4,32-3,68$.

8. Заповніть таблицю:

\begin{tabular}{|c|c|c|c|}
\hline $\begin{array}{c}\text { Вираз } \\
\text { зі змінною }\end{array}$ & $\begin{array}{c}\text { Значення } \\
\text { змінної }\end{array}$ & Числовий вираз & $\begin{array}{c}\text { Значення } \\
\text { числового } \\
\text { виразу }\end{array}$ \\
\hline $\begin{array}{c}(-7,2) \cdot a+a \cdot(-1,3) \\
\left(\frac{4-b}{2(b-3)}+7\right.\end{array}$ & $a=16$ & & \\
\hline
\end{tabular}

9. Прочитайте числові вирази, використовуючи терміни «сума», «різниця», «добуток» і «частка»: $\frac{106-19}{106+19} ;(45 \cdot 32)+(45-32) ; \frac{3}{4} \cdot(3 \cdot 4)$.

10. Наведіть 3 - 4 приклади 3 підручників математики для початкової школи, в яких учням пропонується: скласти вираз до поданої задачі; скласти задачу за даним виразом.

11. Складіть і запишіть три числових вирази, які мають одне й те саме значення, що дорівнює числу 49,75.

12. Запишіть формулу цілих чисел, які при діленні на 3 дають остачу 2.

13. При деяких натуральних значеннях $c$ i $d$ число $3 c+2 d$ ділиться на 7. Доведіть, що при тих самих значеннях $c$ i $d$ на 7 ділиться і число $4 c+5 d$.

14. Запишіть дві істинні рівності та дві істинні нерівності, використовуючи подані вирази: $9 \cdot 3 ; 30-6 ; 3 \cdot 9 ; 30-3$.

15. Відомо, що $a<b-$ істинна нерівність. Поставте замість * знак «>« або «<« 
так, щоб утворилась істинна нерівність:
a) $-3,7 x-7 *-3,7 y-7$;
б) $\frac{x}{7} * \frac{y}{7}$
в) $\frac{2}{7} \cdot(x-1)$
$\left.* \frac{2}{7} \cdot(y-1) ; г\right)-\frac{x}{3} *-\frac{y}{3}$.

Активність студентів - майбутніх учителів початкової школи на лекційних i практичних заняттях 3 математики, висока продуктивність роботи, самостійне продумування завдань, які виконуються в аудиторії (за допомогою викладача і без його втручання), а також старанне виконання домашніх, індивідуальних, самостійних завдань $\epsilon$ свідченням їх стійкого інтересу до математики, до майбутньої професії [9].

Майбутнім учителям початкової школи, крім передавання математичних знань молодшим школярам, доведеться навчати їх самостійно визначати зміст завдання, організовувати діяльність для його виконання [9]. Уміння учнів вільно володіти діями додавання та віднімання (з переходом через розряд і без такого переходу), множення та ділення (багатоцифрових чисел, звичайних i десяткових дробів), а згодом піднесення числа до степеня, визначати залежність між компонентами у математичних записах (не тільки їх знаходження, а й зміну результату відповідно до зміни даних), словесно доводити обраний спосіб розв'язування задачі, вільно оперувати формулами в буквеному вигляді, здійснювати перехід від чисел до реальних об'єктів - стане показником їх усвідомленого вивчення математики на всіх етапах навчальної діяльності, а також оцінкою їх професійної компетентності.

\section{Література}

1. Богданович М. В. Математика: Підруч. для 1 кл. / М. В. Богданович. - К. : Освіта, 2007. - 144 с. 2. Богданович М. В. Математика: Підруч. для 2 кл. / М. В. Богданович. - К. : Освіта, 2010. - 160 с. З. Богданович М. В. Математика : Підруч. для 3 кл. / М. В. Богданович. - К. : Освіта, 2006. - 160 с. 4. Богданович М. В. Математика: Підруч. для 4 кл. / М. В. Богданович. - К. : Освіта. - 2004. - 159 с. 5. Скворцова С. О. Математика. 1 клас : Підручник для загальноосвіт. навч. закладів : У 2 ч. / С. О. Скворцова, О. В. Онопрієнко. Ч. 1, Ч. 2. - Х. : Ранок. - 2012. 144 с. 6. Стойлова Л. П. Основы начального курса математики: [учеб. пособие] / Л. П. Стойлова, А. М. Пышкало. - М. : Просвещение. - 1988. - 320 с. 7. Столяр А. А. Педагогика математики. Курс лекций / А. А. Столяр. - Минск : Вышэйш. шк. / 1969. - 368 с. 8. Тарасенкова Н. А. Використання знако-символічних засобів у навчанні математики : [монографія] / Н. А. Тарасенкова. - Черкаси : Відлуння-Плюс, 2001. - 400 c. 9. Формирование приемов математического мышления // Обучение математике в начальной школе / под ред. Н. Ф. Талызиной, Салмина Н. Г. - М. : ТОО «Вентана-Граф». - 1995. - С. 29-68.

$$
\text { УДК } 371.134+6(07)+004
$$

Станіслав Ткачук

\section{ОСОБЛИВОСТІ ПІДГОТОВКИ ТА ПРОФЕСІЙНОЇ ДІЯЛЬНОСТІ ВЧИТЕЛІВ ТЕХНОЛОГІЙ В УМОВАХ ІНФОРМАТИЗАЦІЇ ОСВІТИ}

Ткачук С. I. Особливості підготовки та професійної діяльності вчителів технологій в умовах інформатизації освіти.

У статті розкрито особливості підготовки та професійної діяльності вчителів технологій в умовах інформатизації освіти, окреслено методичний потенціал інноваційних технологій i шляхи їх упровадження під час самостійної роботи майбутніх фахівців.

Ключові слова: учитель технологій, технологічна освіта, професійна діяльність, 